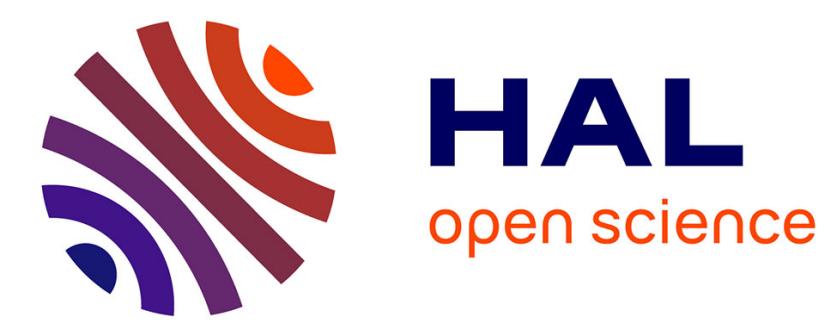

\title{
USE OF NET CAGES FOR FISH FARMING IN SWEDISH CONDITIONS
}

\author{
B. Larsson, K. Ronningen
}

\section{To cite this version:}

B. Larsson, K. Ronningen. USE OF NET CAGES FOR FISH FARMING IN SWEDISH CONDITIONS. Annales de génétique et de sélection animale, 1980, 12 (1), pp.134-134. hal-00893203

\section{HAL Id: hal-00893203 https://hal.science/hal-00893203}

Submitted on 1 Jan 1980

HAL is a multi-disciplinary open access archive for the deposit and dissemination of scientific research documents, whether they are published or not. The documents may come from teaching and research institutions in France or abroad, or from public or private research centers.
L'archive ouverte pluridisciplinaire HAL, est destinée au dépôt et à la diffusion de documents scientifiques de niveau recherche, publiés ou non, émanant des établissements d'enseignement et de recherche français ou étrangers, des laboratoires publics ou privés. 
SIMULATION PROGRAMMES FOR TEACHING ANIMAL BREEDING

\author{
P. M. HOCKING and J. C. BOWMAN
}

Department of A griculture, University of Reading, Early Gate, Reading, England RG6 $2 A T$

The value of Computer Generated Practicals (CGP'S) for teaching genetics and animal breeding is discussed. Programmes for teaching basic Mendelian genetics (Category I), Population and Quantitative genetics (Category II) and Selection in Farm Animals (Category III) are listed. A survey and inventory of CGP's is proposed.

FREQUENCY OF COIOUR GENES IN ICELANDIC SHEEP

\title{
S. ADALSTEINSSON
}

The Agricultural Research Institute Keldnaholt, IIo Reykjavik, Iceland

The paper describes the estimation of the frequency of colour genes at three loci, $A, B$ and $S$, among 134543 Icelandic lambs. At the $A$-locus the frequencies (in brackets) of five, alleles were as follows : $A^{w h}$, white or tan $(0.062) ; A^{g}$, grey (0.100); $A^{b}$, badgerface $(0.007) ; A^{w}$ mouflon (0.012); and $a$, nonagouti (0.279). The frequency of $b$, the recessive allele for moorit (chocolate brown) pigment, was 0.404 , and the frequency of $s$, the recessive allele for white markings, was 0.308 .

USE OF NET CAGES FOR FISH FARMING IN SWEDISH CONDITIONS

\section{B. LARSSON and K. RONNINGEN} Department of Animal Breeding and Genetics Swedish University of Agricultural Sciences
S-750 o7 Uppsala, Sweden

Experimental trials of floating net cages were carried out during 1976 by the Department of Animal Breeding and Genetics of the Swedish University of Agricultural Sciences. The intention of the project was to assess the prospects for fish farming on a commercial basis in Sweden. One desirable effect of this branch of the finishing industry would be to provide employment in sparsely populated areas.

The project was carried out in fresh, brackish and salt water. Altogether eleven net cages, was about 5-6 kg fish per cubic meter. The fish species under study was rainbow trout (Salmo brand "Sterner", of varxing size (50-20o cubic meters) were tried out. Initially, the stocking gairdenevi, Richardson) and they were raised over a 5-6 month season (June-November). Delays in starting the project meant that the season was somewhat shorter than planned. In all the trials, food was given in dry pelleted form.

The summer half-year of 1976 was hot, with relatively high and even water temperatures and in consequence the fish grew rapidly, in most populations achieving a $5^{-6}$-fold increase in weight. The feed conversion ( $\mathrm{kg}$ feed per increase in fish weight) was low for the smaller fish, in the range $1.4-2.0 \mathrm{~kg}$ feed $/ \mathrm{kg}$ weight increase. In the case of larger fish, the feed conversion rate tended to exceed 2.0 slightly, but this was mainly due to the greater feed wastage in these stocks.

The quality of the water in all the trials was good and no substances harmful to fish could be detected.

There were no cases of serious disease and the mortality in the stocks was consistently low (about 2 per cent).

Accretions of algae, snails etc. on the net cages were a minor consideration and did not constitute any hinder to the free circulation of water.

The conclusion drawn from the project was that the raising of fish in net cages is, in Swedish conditions, a method of production which is both biologically and technically sound and worth developing. From an economic aspect too it is likely to prove a branch of the fishing industry with good prospects, especially in the more sparsely populated rural areas. 